\title{
Morality, Coercion and State Building by \\ Campaign in the Early PRC: Regime \\ Consolidation and After, 1949-1956*
}

\author{
Julia Strauss
}

\begin{abstract}
The early to mid-1950s are conventionally viewed as a time when China broke sharply with the past and experienced a "golden age" of successful policy implementation and widespread support from the population. This article shows that the period should be seen as neither "golden age" nor precursor for disaster. Rather it should be seen as a period when the Chinese Communist Party's key mechanisms of state reintegration and instruction of the population the political campaign and "stirring up" via public accusation sessions - were widely disseminated throughout China, with variable results. The campaigns for land reform and the suppression of counter-revolutionaries show that levels of coercion and violence were extremely high in the early 1950s, and the campaign to clean out revolutionaries in 1955 and after suggests some of the limits of mobilizational campaigns.
\end{abstract}

The establishment and evolution of the revolutionary People's Republic of China (PRC) has generated a substantial literature, much of it within the covers of this journal. As there is now access to sources that could only be dreamed about even ten years ago, that literature is on the verge of an important deepening of our understanding of this important stage in the Chinese revolution. And yet, despite this wealth of historical material, current views on the history of the PRC are inescapably coloured by teleology. From the vantage point of 2006, we know that the revolutionary experiment resulted in human, economic and ecological disasters, ending with the waning of the revolutionary impulse by the late 1970s. While this provides a useful and necessary corrective to earlier generations of scholarship, it risks reading later catastrophe back into earlier time periods, when no such outcome was discernible as even possible, much less likely. Nowhere is this more true than in reconsidering the history of the early PRC in its years of regime consolidation and the establishment of socialism (1949-56).

Earlier scholarship and the historiography of the Chinese Communist Party (CCP) itself concur that in its first years in power, the young PRC did an impressive job with regime consolidation. It

* The research for this article was generously supported by grants from the British Academy (International Exchange Scheme with the Shanghai Academy of Social Science), the SOAS Research Committee and the Fulbright Foundation. I owe particular thanks to Elizabeth Perry, R. Bin Wong and Vivienne Shue for their careful readings of earlier drafts. It goes without saying that any errors and omissions remain my own.

(c) The China Quarterly, 2006 doi: $10.1017 / \mathrm{S} 0305741006000488$ 
managed to implement key programmes, from currency stabilization to land reform, to the socialization of industry and enterprise, and an unbelievably rapid collectivization that was pushed through without the kinds of resistance and liquidations that had occurred in the Soviet Union. It managed if not to erase then at least to attenuate the shame of military weakness and foreign influence by fighting the world's then only superpower to a standstill in Korea only a year after coming to power. It made a reasonable showing in the non-aligned movement at Bandung. At least in comparison to what came later, during these years "New China" enjoyed the positive support of a large cross section of the population, enough that a generation, in urban areas at least, looked back to the early to mid-1950s as a veritable golden age; a time when the rhetoric of Chairman Mao actually was reflected by reality: China had finally "stood up."1

Little reconciles this earlier view with what we now know was to come after the years of regime consolidation and the establishment of socialism: the viciousness of the purges, the economic stagnation, the increasingly radical campaigns - one resulting in widespread famine and excess deaths of anywhere from 18 million to 40 million, the other in ten years of protracted trauma, purges, campaigns within campaigns, destruction of higher education and disillusionment of an entire generation of the educated. Given the subsequent history of the PRC, it is difficult for understandings of regime consolidation and the establishment of socialism to be as positively tilted as they were when the Cambridge History of the PRC was written, and scholarship in the past ten years has begun to reflect this. Pieces in edited volumes have begun to question directly whether the early to mid-1950s was really such a "golden age" after all, and are now focusing on the complexity, messiness and contingency of much of what transpired for both individuals and the coalescing state in the early stages of regime consolidation. ${ }^{2}$ Other work considers such topics as bottom-up strike waves in response to the socialization of industry in Shanghai in 1956, the extremity of the tensions and resentments among middle-school teachers that smouldered from the earliest establishment of the educational system, a more critical view of such basic elements of the socialist system as the hukou (户口) registration, and a planned economy that discriminated heavily against the countryside." 3 A

1. For the best compilation of this view, see the essays in John K. Fairbank and Roderick MacFarquhar (eds.), The Cambridge History of China, Vol. 14, The People's Republic, Part 1: The Emergence of Revolutionary China, particularly Frederick Teiwes, "Establishment and consolidation of the new regime," pp. 51-143, and Vol. 15, "Urban life in the People's Republic of China," pp. 682-742.

2. See in particular Paul Pickowicz and Jeremy Brown (eds.), Dilemmas of Victory: The Early Years of the People's Republic of China (Cambridge, MA: Harvard University Press, forthcoming, 2007).

3. See Elizabeth Perry, "Shanghai's strike wave of 1957," The China Quarterly, No. 137 (1994), Eddy U, "Leninist reforms, workplace cleavages, and teachers in the Chinese Cultural Revolution," Comparative Studies in Society and History, Vol. 47, No. 1, pp. 106-133. 
newly emerging generation of scholarship in the PRC has also begun tentatively to re-evaluate key campaigns of the early 1950s, and as these scholars, with even better access to archival materials and interviews, themselves begin to delve into the history of the early PRC, it is likely that even more critical views will be substantiated. ${ }^{4}$

This article attempts to bridge these two basic views by positioning early PRC history (from 1949 to 1956 - the years of regime consolidation and the establishment of socialism) in a wider context of the evolution of the 20th-century Chinese state, whose agenda was to complete the long-standing project to reintegrate the state vertically in a form recognizably "modern," strong and revolutionary. Modernity and strength were pursued on both domestic and international fronts. The state's domestic agenda revolved around promoting industrial growth, wiping out social and normative practices deemed backward and "feudal," and constructing legitimacy for the state; its international agenda played out in the realm of ensuring its own security, and the pursuit of international status and respect, notably in the international socialist movement. The pursuit of all these agendas first required a strong state - one that could simultaneously reintegrate a vast empire after years of fragmentation and warfare, and pursue a range of developmentalist and revolutionary programmes for action. In outlining the broad trajectory of domestic state reintegration in the early to mid-1950s, I make three arguments: first, there was substantial continuity across the divide of 1949 as the young PRC managed to implement many of the state building projects first aspired to by the departed Kuomintang (国民 党, KMT) regime; secondly, its chosen manner of implementation was through simultaneously launching state building initiatives and mobilizational campaigns (qunzhong yundong 群众运动); and thirdly, its success in both state building and campaigns resulted from a distinctive blend of coercion and normative appeals it applied to both the implementing agents of the state (cadres) and society at large, buttressed throughout by a didactive self-confidence in its own moral rightness, unique vision and claims to transform past injustices while leading China into the future.

Little of this is at substantive odds with more critical recent assessments of the PRC. "New China" was highly coercive, it did create a de facto caste system of status that led to systematic

4. Gao Hua, Shenfen he chayi: 1949-1965 nian Zhongguo shehui de zhengzhi fenceng (Status and Difference: Political Stratification in China, 1949-1965) (Hong Kong: Hong Kong Institute of Asia Pacific Studies, 2004); Yang Kuisong, "Xin Zhongguo gonggu chengshi zhengquan de zuichu changshi - yu Shanghai 'suofan' yundong zhongxin de lishi kaocha" ("The first attempt to consolidate political power in cities: a historical analysis of the 'suofan' movement in Shanghai"), online paper at www.coldwarchina.com, and Zhang Jishun, "Shanghai linong jiceng zhengzhi dongyuan yu guojia shehui yitihua zouxiang" ("Shanghai neighbourhood grassroots political mobilization and tendencies toward national integration"), Zhongguo shehui kexue (Chinese Social Sciences), Vol. 146, No. 2, pp. 178-188. 
discrimination and high levels of tension between city and countryside and within work units, and ideologically driven campaigns did ultimately exhaust and terrorize the population at large. However, work that turns a critical eye on such different social sectors as school teachers, intellectuals and workers may sidestep a larger question of the whole: the regime's own goals in the context of an even larger, century-long project of state (re)integration. The regime's early successes on its own terms were real, and merit (re)consideration in the light of increasingly available sources. The successful regime consolidation of the revolutionary PRC owed much to its inheritance from the KMT and its own superiority in definitively "outgeneralling" the KMT military in the civil war and crushing all meaningful military resistance. The overwhelming and unexpectedly quick military victory created the necessary, but still insufficient, conditions for the establishment of a state strong enough to implement a wide range of revolutionary policies, and fundamentally remake the basic institutions of government and society. This article elaborates the mechanics by which the "sufficient" conditions for the revolutionary transformation of society were implemented: the CCP's particular mix of coercion and engaging the emotions with positive moral appeals, its frequent and successful application of campaigns to push through new policies, and its absolute confidence in its own moral correctness despite logical contradictions in the way its ideologically driven categories made sense of reality. In so doing, New China frequently reneged on its own promises, and it proved repeatedly willing to inflict substantial collateral damage on those unlucky enough to be on the wrong side of shifting definitions of "the enemy." The early to mid-1950s was not a "golden age." But nor did it necessarily contain the seeds of its own destruction.

\section{Institutional and Ideational Legacies from the Republican Period}

The issues the young PRC faced were indeed severe. When set in its own time and juxtaposed against its immediate predecessor, its accomplishments were impressive. The revolutionary regime was ideologically driven, and its ideology had to be brought into line with a daunting range of "objective" problems, starting with hyperinflation and a ruined economy, a high population to arable land ratio, a mistrustful population and weak roots in the broad swathes of the central and southern parts of the country, and the economic, social and political legacy of a generation of unrelenting civil war and foreign invasion.

The PRC built on the institutional and ideational legacy of the KMT. Like all revolutionary regimes, its rhetoric drew a sharp line between it and the immediately preceding (and now de-legitimated) ancien régime. But in fact the PRC was a revolutionary regime that substantially conformed to de Tocqueville's key reflection on the French revolution: the revolution quite literally completed the work of 
the old regime, with "a central authority with powers stricter, wider, and more absolute." When one looks closely at what was done in a macro sense rather than what was said, there was substantial extension of not only the CCP's own pre-1949 traditions and legacies of class struggle and mass line, but those of the now-vilified KMT. The KMT's weaker, looser version of party-state was the first to attempt to educate a citizenry in a modern zhengdang (政党) culture, the first to launch a society-wide urban movement (the New Life Movement), the first deliberately to pair moral incentives with the structural, technocratic and "scientific," the first to be heavily militarized in terms of both the rhetoric and models used, and the first to adopt a widely statist takeover and nationalization of industry. ${ }^{6}$ Some of the reasons for this lie in a shared agenda of vertically reintegrating the state along "modern" lines. Others are a result of institutional and temporal conditions: a legacy of revolution and tutelage based on the Leninist party-state (yi dang zhiguo 以党治 国), and subjection to the same relentless militarization of the Republican period - a militarization that only intensified over the course of the 1940s. Like the CCP, the KMT made serious attempts to partify the state bureaucracy from the late 1930s on, carried out extrabureaucratic attempts to mix technical training and ideological education for state agents, and liberally used military metaphors and imagery at the core of state ideology. ${ }^{7}$ Many of the features associated with the People's Republic of China were first attempted under the Nationalist regime, but with only variable and limited successes that were eventually undercut by a combination of poor military strategizing and a complete loss of control over the economy during the 1940 s.

Not only were there substantial continuities in the basic agenda of the state, but many of the strategies to implement that agenda were carried across the divide of 1949 , albeit in a much stronger form than their pre-1949 variants. For both Nationalists and Communists, almost all solutions to problems of economy, industry and defence

5. Alexis de Tocqueville, The Old Regime and the French Revolution (trans. Stuart Gilbert) (Gloucester: Peter Smith, 1978), part 3, ch. 8, "How, given the facts set forth in previous chapters the Revolution was a foregone conclusion," p. 209.

6. Henrietta Harrison, The Making of the Republican Citizen: Political Ceremonies and Symbols in China, 1911-1928 (Oxford \& New York: Oxford University Press, 2000),William Kirby, "Continuity and change in modern China: economic planning on the mainland and on Taiwan, 1943-1958," Australian Journal of Chinese Affairs, No. 24 (1990), pp. 121-141, Mark W. Frazier, The Making of the Chinese Industrial Workplace: State, Revolution and Labor Management (Cambridge: Cambridge University Press, 2002), chs. 2-3 (pp. 23-91).

7. Julia Strauss, "Strategies of Guomindang institution building: rhetoric and implementation in wartime Xunlian," chapter in Terry Bodenhorn (ed.), Defining Modernity: Guomindang Rhetorics of a New China, 1920-1980 (Chicago: University of Michigan Press, 2002), pp. 195-222. See also Elizabeth Perry, Patrolling the Revolution: Worker Militias, Citizenship, and the Modern Chinese State (Lanham: Rowman and Littlefield, 2006), ch. 3 "China's first Leninist party-state, 1927-1949" and ch. 4 "China's second Leninist party-state, 1949-1965," for the Kuomintang antecedents to workers' militias. 
were conceived of in statist terms; a vertically integrated unitary state of education and moral indoctrination for the untutored population was presumed to be a part of the answer to most questions, and even a hint of any federal solution completely inconceivable. The PRC was of course not identical in organization, programmes or ethos to the outgoing KMT. It had three extraordinary advantages that the KMT never possessed: the dominant military control over the vast territory of China that made it possible to impose coercive measures against "enemies" and stir up or dampen down popular participation; an ideology of class struggle that did not hesitate to suppress those deemed recalcitrant or blocking the revolutionary cause; and most distinctively the self-confidence and willingness to call upon mass mobilization in support of its policies.

\section{Rethinking Campaigns: State Building by Institutionalization and Mobilization}

The young PRC's chosen strategy of regime consolidation and establishing socialism was through, first, establishing and strengthening the coercive and infrastructural capacities of the party-state, and, secondly, launching political campaigns of mobilization. Scholars working on the contemporary period have begun to differentiate between Mao and post-Mao types of campaigns, with a "classic" Mao-era version that involved high degrees of mass mobilization, and a post-Mao variant in which campaigns devoid of any mass mobilizational element are launched by the leadership to focus the state bureaucracy on enforcement of previously existing rules and laws. But most of what has been written on the Maoist period stresses the importance of campaigns of mass mobilization while very little attention is paid to other sorts of campaigns. ${ }^{8}$

Since archives have begun to open and access to original documents written by and for the bureaucracy in the 1950s has increased, it is now possible to distinguish analytically between not two but as many as four different types of campaigns in the years before the Eighth Party Congress. The first was the kind that, like its post Mao variant, focused the attention of the bureaucracy in a particular policy area with the ultimate "target" the mobilization of the commitments and focus of the bureaucracy itself. The big pushes to register the population, construct granaries and train politically reliable police forces of the early 1950s, and the 1955 nationalization of private

8. For the clearest articulation of Mao and post-Mao types of campaigns, see Melanie Manion, Corruption by Design: Building Clean Government in China and Hong Kong (Cambridge, MA: Harvard University Press, 2004), ch. 5, "Anticorruption campaigns as enforcement mechanisms," esp. pp. 156-163 and 168-172). Charles Cell offers a typology of campaigns that includes the lesser known ones in Revolution at Work: Mobilization Campaigns in China (New York: Academic Press, 1977), but does not go much beyond typology. See also Gordon Bennett, Yundong: Mass Campaigns in Chinese Communist Leadership (Berkeley: Institute of East Asian Studies, 1976). 
enterprise are the most obvious examples of this type of bureaucratic campaign. They concentrated on a particular problem of governance or society, but did not particularly attempt either to mobilize social support or to change the behaviour of relevant social groups. The second was the frequent, more limited type of campaign that was implemented through the bureaucracy to achieve some combination of behavioural change and positive normative commitments of a relatively restricted social or occupational group. The best examples of this were the early campaigns to wipe out prostitution and opium addiction, the thought reform campaign of 1953 aimed at intellectuals, and those directed at raising productivity in particular industries that took place throughout the 1950s. The third type of campaign involved both the bureaucracy and the citizenry more generally in effecting transformation of both the environment and behaviour, often in the realm of public health and hygiene, exemplified by tree planting and irrigation campaigns, and the campaigns against schistosomiasis and the "Four Pests." Finally there were what we think of (and what the PRC itself continues to identify as) the "classic" and important political campaigns of the early PRC, the great mass qunzhong yundong that took place from 1950 to 1953: the Aid Korea/Resist America campaign of autumn 1950, the Campaign to Suppress Counter-revolutionaries of 1951, the Three-Antis and Five-Antis campaigns of 1952-53, and the land reform campaign, which took place at various times in different parts of the country, but was everywhere completed by the end of 1952 . These highly visible and well publicized campaigns were characterized by the bureaucracy mobilizing very large segments of both rural and urban populations to gain popular support and high degrees of mass participation in favour of state-determined policies and outcomes. In the early to mid-1950s, the practical distinction between campaigns of bureaucratic intensification and campaigns of partial or mass mobilization was in practice much less clear than it became in the post-Mao era. Each had as its first target the mobilization and intensification of urgency within the bureaucratic institutions of state, but three of them went beyond the state itself as state agents pushed hard for a measurable degree of change in normative commitments and/or behaviour from either targeted social groups or society at large.

Although we are used to thinking of this most visibly public form of mass campaign as something particular to the Chinese Communist Party, in 1949 there were two other producers of campaigns or campaign-like behaviour to which the $\mathrm{CCP}$ could refer; the

9. See Joshua Horn, Away With All Pests: An English Surgeon in China (London: Paul Hamlyn, 1969), especially ch. 10, "Death to the snails! The fight against schistosomiasis," pp. 94-106, David M. Lampton, The Politics of Medicine in China: The Policy Process, 1949-1977 (Boulder: Westview Press 1977), and Judith Shapiro, Mao's War Against Nature: Politics and the Environment in Revolutionary China (Cambridge: Cambridge University Press, 2001). 
pre-existing Nationalist regime in China and Stalinism in the Soviet Union. Yundong (运动), state-led instruction in changes in behavioural norms with a limited version of mass mobilization, was recognizably part of the zhengdang (政党) political culture of the Nanjing Decade (1927-37), with the notoriously unsuccessful New Life Movement as its best example. ${ }^{10}$ Like the wider state-building agenda of vertical reintegration and expansion of state power inherited from the KMT, the CCP extended and expanded a key vehicle first attempted, albeit unsuccessfully, by its immediate predecessor, in an ultimately much stronger and effective form. And while different in other respects, Stalinism's Stakhanovite movement resulted in processes that had close analogies in most of the mass campaigns of the early PRC: the singling out of a minority of enemies (variously called "wreckers," counter-revolutionaries, landlords, or corrupt bureaucrats or businessmen) as a way of mobilizing the majority in favour of intensive pushes for party-state determined policies. ${ }^{11}$ Campaigns of mobilization - be they of the general population, specific target groups or the bureaucracy itself - had precedents in the Republican period and referents elsewhere in the contemporary Leninist world, to say nothing of the CCP's own experiences with mass mobilizational techniques in urban areas in the 1920 s and the countryside in the 1930 s and 1940 s. $^{12}$

What was so distinctive about the CCP's implementation of campaigns was neither its reliance on its categories of class struggle for the identification of enemies (as in the Soviet Union under Stalin) nor its belief in its own educative morality and ability to set the terms of individual self-cultivation for the individual to transform himself through a process of small-group study and self-criticism (as for the KMT in the 1940s and 1950s), but the CCP's genuine desire for popular participation, and its unusual degree of confidence that with proper education, the ultimate support of a broad cross-section of both rural and urban society for its policies would be present. Campaigns mobilized individuals in support of regime-determined goals, but they also coerced in subtle and indirect ways. The campaign mentality of activating collective emotions and heightening awareness

10. Arif Dirlik, "The ideological foundations of the New Life Movement: a study in counterrevolution," Journal of Asian Studies, Vol. 34, No. 4 (1975), pp. 945-980. The New Life Movement ran aground on its desire simultaneously to foster mass mobilization while keeping it within strict, state-determined limits.

11. Hiroaki Kuromiya, Stalin's Industrial Revolution (Cambridge: Cambridge University Press, 1988), pp. 31-35 on campaign purges and pp. 195-99 on radical worker mobilization.

12. The literature on these topics is vast, but for relatively recent treatments of the former, see S.A. Smith, Like Cattle and Horses: Nationalism and Labor in Shanghai (Durham: Duke University Press, 2002), For the latter, the classic general treatment remains Mark Selden's China in Revolution: The Yenan Way Revisited (Armonk: M.E. Sharpe, 1995). See also Odoric Wou, Mobilizing the Masses: Building Revolution in Henan (Stanford: Stanford University Press, 1994) and Yung-fa Chen, Making Revolution: The Communist Movement in Eastern and Central China, 1937-1945 (Berkeley \& Los Angeles: University of California Press, 1986). 
made it a formidable tool for conformity (and driving alternative, critical opinions underground); campaigns also created an environment in which it was relatively easy to establish and/or strengthen the regular, "normal" institutions of police and security committees. ${ }^{13}$ Through the vehicle of the campaign, the $\mathrm{CCP}$ was both willing and able to mobilize tactically both the regular bureaucracy and the population at large to isolate putative "enemies," overcome resistance in order to push through key programmes, establish the more workaday institutions of state coercion and draw out a widespread support for the regime that was simply assumed to be there.

In so doing, the party-state at the centre and the provincial, municipal and local cadres on whom it relied for implementation throughout the country relied on a distinctive blend of constantly shifting tactics: paternalism alternated with coercion, and populism with monocratic control. ${ }^{14}$ Earlier generations of political scientists have long understood the revolutionary PRC in terms of its internal contradictions: the simultaneously articulated trends towards institutionalization and campaign mobilization and voluntarism that were at the very least in tension with each other. ${ }^{15}$ Similarly, historians such as Maurice Meisner have long grappled with what many see as Maoism's inherent contradiction: simultaneously desiring popular mobilization and the people taking charge of their own revolution, and the need to guarantee the monocratic party-state's own desired outcomes through a process of heavy-handed control. ${ }^{16}$

While these tensions certainly existed in the later years of the revolutionary PRC, the coexistence of such logically incompatible phenomena as institutionalization with extraordinary mobilization, paternalism with terror, populist participation with party-state control, and all of the above with a larger revolutionary state's processes of regime consolidation and the establishment of the basic institutions of socialism, was not the "problem" that it became later. On the contrary, until at least 1953, campaigns cleared the ground for institutionalization by weeding out enemies and instructing the population in new norms of political culture and acceptable behaviour, paternalism rhetorically geared to the many made terror easier to implement against the few, and, when appropriately "stirred

13. On the skilled way in which the Communists engaged in "emotion work," see Elizabeth Perry, "Moving the masses: emotion work in the Chinese Revolution," Mobilization, Vol. 7, No. 2 (2002), pp. 111-128.

14. Elsewhere, I describe this dynamic as "paternalist terror"; see Julia Strauss, "Paternalist terror: the campaign to suppress counterrevolutionaries and regime consolidation in the People's Republic of China, 1950-1952," Comparative Studies in Society and History, Vol. 44, No. 1 (2002), pp. 80-105.

15. Lowell Dittmer, Liu Shao-chi and the Chinese Cultural Revolution: the Politics of Mass Criticism (Berkeley \& Los Angeles: University of California Press, 1974), pp. 3-4, 185-186, 211.

16. Maurice Meisner, Mao's China (and After): A History of the People's Republic (New York: Free Press, 1977 and 1999), in 1977, pp. 385-86. 
up," the masses did usually, although not uniformly, produce the kinds of results that the party-state wanted.

\section{Morality, Coercion and State Expansion: Land Reform and the Campaign to Suppress Counter-revolutionaries}

In 1951, the CCP launched two important political campaigns of mass mobilization, which taken together were aimed at mobilizing both rural and urban populations against a small minority of designated "enemies." These campaigns were not only "effective" in terms of accomplishing their key goals of land redistribution and identification and prosecution of enemies of the state. They were also an "efficient" means of implementing different things at once. They communicated the key elements of the leadership's particular ethos of class struggle as well as the economic, social and political categories by which class struggle was understood; transferred significant resources to key groups upon which it relied for support while physically destroying social and economic status groups who could block state initiatives for remaking the countryside; mobilized the majority of both urban and rural China into active support for, and complicity in, regime violence against those designated as internal enemies; and created a political atmosphere in which it was possible to begin the process of expanding the presence of the state at increasingly local levels.

Land reform in the countryside and the Campaign to Suppress Counter-revolutionaries in urban areas were undertaken at roughly the same time for those areas outside north and north-east China that had not already undergone land reform, and in central and south China they were concurrent and deliberately overlapping in the suburban borderlands between city and countryside. Both were geared at eliminating groups the regime considered to be key political, social and economic competitors: landlords in the countryside, exKMT military and party personnel with high rank; and a much larger range of assorted social undesirables such as bandits, local bullies, the leaders of counter-revolutionary religious sects and low level hoodlums hanging out on the streets. Both campaigns went directly to the population at large - the masses of both city and countryside to elicit popular support for the regime's policies of mass transfer of property and crackdown on suspected political undesirables through the heavily stage-managed spectacle of accusation meetings (kongsu hui 控诉会) against individuals designated as enemies. Both used high degrees of state-sanctioned violence, with millions executed. And they left in their wake a much augmented state presence, in terms of expanded numbers of cadres and direct state organization of ever smaller units of society. They were both predicated on domestic components of the regime's internal state-building agenda: mobilizing support from society and stiffening the resolve of state cadres, and 
drastically expanding the coercive capacity of both the regular bureaucracy and new state organizations.

The first thing that stands out about the Campaign to Suppress Counter-revolutionaries and land reform is the contrast between their harshness in terms of rhetoric, implementation and sheer physical violence, and the tentative, careful and conciliatory way in which the CCP took over the big cities of the south and reassured the country at large upon coming to power in 1949. Depending on which set of incomplete statistics one refers to, the casualties incurred in these two campaigns probably ranged between a low estimate of one million and a high estimate of upwards of five million either sentenced to death by the state or spontaneously killed in the highly emotionally charged atmosphere of public accusation meetings. ${ }^{17}$ The violence of these campaigns was inseparable from a wider regional context of deepening Cold War and China's involvement in the Korean War, and indeed the formal dates of the Campaign to Suppress Counterrevolutionaries are almost identical to the dates of China's open involvement in the Korean War. But their intent and main outcomes were domestic, signalling to a range of domestic constituencies (cadres in the bureaucracy itself, the social base from which the basic-level cadres of the state were to be recruited, unaligned social groups in city and countryside, and the campaign's designated "enemies" and their sympathizers) that conciliation was over and that the revolutionary regime meant business. Never again did the regime launch such united and deliberate campaigns to exterminate targeted social groups. Nor did it feel it needed to. Later target groups of mass campaigns such as entrepreneurs (the Five-Anti's), "corrupt" bureaucrats (the Three Anti's), intellectuals (the Thought Reform Campaign, the Anti-Hu Feng Campaign and even the vicious Anti-Rightist campaign) were

17. There are only rough estimates and inconsistent numbers on the total numbers executed and killed during these two campaigns. Frederick Teiwes suggests a lowerend estimate of between 200,000 and 800,000 (Teiwes, "Establishment and consolidation of the new regime," n. 24), while Jurgen Domes offers a figure of "no less than 5,000,000" in The Internal Politics of China 1949-1972 (New York: Praeger 1973), p. 38, and Richard Walker's highly critical China Under Communism; The First Five Years (London: Allen and Unwin, 1956) p. 137, offers a "conservative" figure of $1,500,000$. The official numbers on the Campaign to Suppress Counter-revolutionaries vary between 700,000 and two million. Domes cites two figures: the lower end of 800,000 executed was released at the Eighth Party Congress in September 1956, but a work report released by Bo Yibo in 1952 referred to a much larger number of 2,000,000, The Internal Politics of China, p. 52. Statistics were collected, but inconsistently, and categories of classification were at best ambiguous. In peri-urban areas and the countryside, counter-revolutionaries and landlords were often lumped together (and so would have been reported to different sub-bureaucracies). However, on the whole the bureaucratic incentives were likely to lead to under-counting rather than over-counting. Landlords who died of injuries inflicted by crowds in the course of accusation meetings were often not recorded as executed, because this reflected badly on the local cadres' control of the situation. There was also substantial variation in how vigorously the campaigns were executed in different regions. The Jiangnan seems to have been relatively mild, and the still unsecured rural south-west very harsh: here upwards of another million "bandits" were "suppressed," variably classified as bandits or counter-revolutionaries. 
subject to mass criticism, thought reform, internal exile, loss of position and lengthy jail sentences, but were rarely, if ever, executed. The severity of these two campaigns of regime consolidation reflected the leadership's surprising degree of self-confidence in the inherent moral "rightness" of hitting hard at "enemies," its need to mobilize the lower reaches of the bureaucracy to implement such violence, and its absolute certainty that with proper instruction and organization, the support of the "masses" was a foregone conclusion, even when there were objective grounds for having doubts.

For example, when land reform was implemented between 1950 and 1952 in the country at large, there was a fundamental problem with the leadership's conceptualization of this very important part of the revolution as both "scientific" and morally and materially necessary. The Marxian system of economic classification by which rural society in China was understood had been developed in the particular context of north China. Here, despite questions about where particular individuals in a village stood, the standard categories of landlord, rich peasant, middle peasant and poor peasant and the idea of exploiting classes were comprehensible and broadly applicable. ${ }^{18}$ When the CCP implemented land reform in the more commercialized and commodified countryside of the lower Yangtze region, it found that these received categories simply did not apply at all. A majority of the working rural population only engaged in agricultural production part time if at all, most males aspired to work in factories and many succeeded in so doing, absentee landlords were the rule and indeed in many cases had to be brought back to the countryside to be struggled against, and even small producers with low incomes frequently rented out all or part of their landholdings. The more commercialized and impersonal economic relations of the Jiangnan made it significantly harder to stir up class hatred against the actual exploiters than was the case in north China. In the south the real hatred of the common people was directed against the resident agents and rent collectors for absentee landlords. ${ }^{19}$ Indeed, in at least some districts, the majority of those targeted and struggled against were not landlords at all. For example in Shanghai county, of the 779 individuals subjected to mass struggle sessions in 1951, only a quarter (200) were landlords. Local bullies accounted for 140, counter-revolutionaries for 239, and a catch-all category of "other" for $213 .^{20}$ Nevertheless, despite the

18. On the difficulties of classifying individuals, see William Hinton, Fanshen: $A$ Documentary of Revolution in a Chinese Village (Vintage Books, 1968), esp. pp. 28587, 303-305. Even in north China these categories can be questioned, as there was relatively little economic stratification compared to the south; in northern rural China almost everyone was poor in absolute terms.

19. Shanghai Municipal Archives (SMA) A71/1/71, "Shanghai shi jiaoqu tudi gaige zongjie" ("Comprehensive summary of land reform in suburban Shanghai"), 25 November 1952, pp. 2-5 of internal report.

20. Minhang District Archives (MHA) 13-1-37. "Shanghai xian jiesu tugai gongzuo douzheng tongjibiao" ("Shanghai county statistical table: struggle work on the completion of land reform"), dated 18 November 1951. 
objective special circumstances and social complexity of the region and cadres' own awareness of the importance of avoiding mistaken oversimplification through "pure struggle against landlords" (danchun douzheng dizhu 单纯斗争地主) when those who rented land were often themselves middling smallholders, in the final analysis the same categories of Marxian class analysis and targets of struggle were applied to the greater Shanghai area with only minor modifications.

Regime self-confidence, articulated through a particular version of morality and socio-economic justice, was also manifested in the way in which a range of different social groups was brought in to support and implement land reform. The young People's Republic made extraordinary efforts to mobilize the patriotic and moral commitments of basic-level cadres of poor peasant background (many of whom were not Party members at all), middle school and university students, representatives from democratic parties, and even scholars from the higher reaches of academia in Beijing. Land reform went hand in hand with a substantial expansion of the ranks of basic-level cadres in the countryside. In the Shanghai suburbs alone, 4,616 activists were identified and trained, of whom over one-fifth $(1,042)$ were promoted to the ranks of regular cadres, and overall some 6,481 cadres were promoted, with the vast majority $(6,005)$ from poor and middle peasant backgrounds. ${ }^{21}$ But it wasn't only poor and middle peasants who were drawn in to the state's basic structures and agenda.

Special teams of local-level and nationally known academics and social science researchers were also inculcated into regime norms of Marxian categories through ideological training, and sent to the countryside first to record the "objective" social and economic conditions of "feudal" impoverishment and stratification, and then deployed on behalf of the state to implement the regime's programme of land reform. Academics from Beijing's elite universities were sent to the Jiangnan as special land reform teams to investigate conditions and participate in land reform, eventually writing up widely disseminated reports on their experiences for the rest of the country. ${ }^{22}$ In the spring of 1951 another special team - this time representatives of China's democratic parties - was chosen by the Political Affairs Department of the Central People's Government to follow suit. ${ }^{23}$ A much larger number of 460 lecturers from local universities and senior

21. SMA B14/1/80, "Shanghai shi jiaoqu xunlian ganbu shu peiyang jijifenzi qingkuang" ("Situation on Shanghai municipal outlying district cadre training division's activist training"), and "Sheng tudi gaige qianhou xiangcun jiceng ganbu bianhua qingkuang tongibiao" ("Statistical form on changes in basic level rural cadres before and after land reform") both p. 13 of internally numbered file dated 31 December 1951.

22. "Beijing ge daxue jiaoshou huadongqu tudi gaige canguan tuan zongjie" ("General summary of Beijing universities' professorial group visiting tour of the Eastern China region land reform"), Wo suodaode sunan tugai yundong (Shanghai: Shanghai jiaoqu he sunanqu tudi gaige weiyuanhui, 1951).

23. Jiangsu Provincial Archives (JPA) 3006-2-224 "Guanyu canjia sunan tugai ge zhong minzhupai qingkuang" ("Situation on democratic groups' participation in land reform in South Jiangsu"), 16 May 1951. 
middle schools in the greater Shanghai area were similarly trained and organized into special teams to carry out land reform directly in the countryside surrounding Shanghai, and students and recent graduates were especially sought out for land reform teams as well - at least in part because their literacy could be counted on. ${ }^{24}$ While it is impossible to evaluate whether these individuals actually believed in the new categories of social understanding such as "feudalism" and "exploiting classes" or whether their reports and memoirs were edited to reflect regime objectives, what does stand out is the degree to which many non-Marxist academics and intellectuals so quickly adapted to behaving and writing as if they really did accept these new categories of Marxian diagnosis of social problems. Testimonials from the time and an enormous memoir literature may be epistemologically suspect, but behaviour suggests that many did actively participate in the land reform campaign, pushing through the regime policy "cure" of land reform through identification of class enemies, mass struggle sessions, redistribution of land and overcoming poverty through the beginning of voluntary co-operativization. ${ }^{25}$ As it set about inculcating a set of new, revolutionary norms in tandem with the nuts and bolts of state reintegration, the regime's didactic self-confidence in the historical correctness of the categories by which it understood social and economic relations was surely an important component of its willingness to mobilize the emotional affect and moral outrage of its citizens at polar ends of society - from poor peasant to privileged intellectual. ${ }^{26}$

The concurrent and partially overlapping Campaign to Suppress Counter-revolutionaries was run through the regular institutions of the party-state rather than specially detached work teams and newly recruited local cadres, but it exemplified state strengthening in two other respects: stiffening the resolve and overcoming the natural scruples of provincial and sub-provincial cadres, while expanding the directly coercive institutions of the state. ${ }^{27}$ In the key announcement that launched the campaign on 10 October 1950, the Party sharply reversed its earlier policy of "excessive lenience” (kuanda wubian 宽大

24. The reports and experiences of individuals in the special Beijing team were published in a variety of places, including People's Daily, and then put together into a special published collection Wo suo kandao de sunan tudi gaige yundong (The Land Reform in Southern Jiangsu I Witnessed), edited by Sunan renmin gongshu tudigaige weiyuanhui, and brought out by the Shanghai outlying district committee on land reform in late 1951. On the special training and organization of lecturers and senior high school teachers in work teams to carry out land reform, see SMA B14-1-6 and passim "Jiaoshi canjia tudi gaige di'yi xiaozu mingdan ji duiyuan dengjibiao" ("Registration form for the first small group of instructors participating in land reform: name lists and group members") (1951).

25. Lisa Wedeen, "Acting 'as if" symbolic politics and social control in Syria," Comparative Studies in Society and History, Vol. 40, No. 3 (1998), pp. 403-423.

26. Shi Wenqi, "Wo suo jiandaode su'nan tudi gaige yundong" ("The land reform movement in Sunan that I saw"), in The Land Reform in Southern Jiangsu I Witnessed, pp. $88-89$.

27. Some of the information below on the Campaign to Suppress Counterrevolutionaries is also covered in much greater detail in Strauss, "Paternalist terror." 
无边) in favour of "combining suppression and lenience" (zhenya kuanda jiehe 镇压宽大结合) and exhorted local cadres to enact a harsh policy of "executing some, imprisoning some and putting some under house arrest." 28 The problem for local cadres was that the slogan of "combining suppression with lenience" was vague enough to mean almost anything. Many couldn't understand why it was necessary to crack down so hard on counter-revolutionaries, especially as most of the political counter-revolutionaries who had held high positions in security or party organizations for the KMT had already been promised lenience if they came forward and registered with authorities. At least in the Jiangnan, a natural reluctance to be the instruments of state violence led to significant foot-dragging in campaign implementation. Until Luo Ruiqing went on tour and publicly reprimanded most of the big cities of the south in late March 1951, many local cadres felt that counter-revolutionaries could be won over by intensive re-education, wondered why the Party was so abruptly cancelling its own promises of lenience to those who came forward and registered, doubted the necessity of shooting people, and denied that their own offices could possibly harbour counter-revolutionaries. ${ }^{29}$

The Campaign to Suppress Counter-revolutionaries also led to a direct and significant expansion of the security and coercive instruments of the state, which grew hand-in-hand with a new culture of informing and obsession with secrecy. In the general atmosphere of panic and hysteria about counter-revolutionaries and sabotage, local cadres were exhorted to strengthen security work, extend surveillance, and build up the police by recruiting the young and politically reliable to phase out the then more numerous KMT leftovers. Local security committees set up ad hoc sites to register free-floating counterrevolutionaries, and began what would turn out to be a lengthy process of directly imposing vertically integrated lines of security reporting in large factories, government offices and schools. In the late spring of 1951, the Eastern China military region security headquarters sent over 400 cadres to important factories in Shanghai

28. The "Double Ten" Directive that launched the campaign is reproduced in Jianguo yilai zhongyao wenxian xuanbian, Vol. 1 (Beijing: Zhongyang wenxian chubanshe, 1992), p. 421, and Luo Ruiqing's formula of "executing some, imprisoning some and confining some to house arrest" in "Zhonggong zhongyang pizhuan zhongyang gong'an bu 'guanyu quanguo gong'an huiyi de baogao' ("The Chinese communist central approved and circulated central Ministry of Public Security 'Report on the national public security conference"'), 28 December 1950, ibid. p. 443.

29. See in particular SMA A22/2/50, "Shifu jiguan ganbu buchong tianbiaozhong de xuanchuan jiaoyu gongzuo zongjie" ("General report on propaganda and education work for municipal organization cadres' supplementary form completion"), 31 July 1951, and SMA S64-4-134, "Shanghai shi zaoqi gongye tongye gonghui, 'Benhui huiyuan xuexi zhenya fangeming shi zhengci de xuexi jihua he zongjie baogao"" "'Shanghai municipal preliminary same industry society 'General report and study plan for society's members study of the principles for the suppression of counterrevolutionaries"'), 5 June 1951. 
to set up these committees and provide advice and support on the implementation of the campaign. ${ }^{30}$ But of course once these footholds were established the CCP presence did not fade; it only became stronger, and much expanded with subsequent campaigns. In both urban areas and the countryside the campaigns of 1951 led directly to the expansion of the state in terms of its numbers of agents, and to the beginnings of its direct intrusion on the everyday workings of the work place.

\section{Bringing in the Masses: Campaign as Show}

By either Leninist or Chinese traditions of statecraft, the young PRC was unusual in the degree to which it openly solicited the participation and support of its urban and rural populations, and the degree to which this took place in open, public space. Both land reform and the Campaign to Suppress Counter-revolutionaries had, as their dénouement, a form of populist participatory theatre in the form of kongsu hui (控诉会), public mass accusation sessions against defined class enemies. The public accusation meeting was, quite literally, a show put on by the new state, replete with staging, props, stock characters, rough working scripts, dramatic peaks and a good round of final applause. Mass accusation meetings against both counter-revolutionaries and landlords (in the Jiangnan the two categories frequently overlapped) were not the formalized, bureaucratic affairs of woodenly delivered show trials of the Soviet Union, they were deliberately used as a heuristic devise to engage the emotions of the public, whip up hatred against designated class enemies and mobilize the masses into positive support for the regime. Every urban area held mass accusation meetings against counterrevolutionaries, as did most villages against landlords; and when sufficient landlords could not be produced, "local bullies" and other power holders under the old regime, particularly those who had actively collaborated with the Japanese, filled in.

This account of an accusation meeting in Mulan (木兰) county in rural Heilongjiang gives a sense of the public face of these events:

On August 14 [1951], the public judgement of Wang Hanwu and the others was held in the county seat's people's primary school.

At around 7.00 to $8.00 \mathrm{am}$, group by group the masses began to filter in. There were weathered old people, children closely following their parents ... over 150 women with babies in their arms walked for 20 or 30 kilometres to come to the occasion. People came from all corners, filling the schoolyard, packed into the surrounding neighbourhood, and looked out from every nearby window.

At $9.00 \mathrm{am}$, Chair Xie Wanzhun opened the meeting. 14,000 pairs of eyes avidly focused on the rostrum. The chair explained the significance of the meeting, and the chief prosecutor, Zhu Hong, read out the charges:

30. SMA C1/1/28, "Shanghai gongren canjia zhenya fangeming yundong zongjie baogao" ("Summary report on Shanghai worker's participation in the campaign to suppress counter-revolutionaries"), July or August 1951. 
"Wang Hanwu, Sun Shengye and other traitorous thieves, under the Japanese occupation you cruelly oppressed the people, impressed forced labour, drafted soldiers, commandeered grain, suppressed our anti-Japanese soldiers and people, and killed who knows how many. As leader of the intelligence association, Wang Hanwu accused 100+ people and arrested over 20."

Prosecutor Song continued: "tewu group leader Sun Fujiang arrested over 70 anti-Japanese resisters. Head of police Wang Jiadong set up a bandit area, terrorized villagers into fleeing, and killed many." He concluded "Puppet county chief Ji Liang not only did the bidding of the Japanese, he even continued his counter-revolutionary activities after the Japanese were vanquished, scheming to establish a bandit military ... fighting against the liberation of Mulan. These guys have blood debts piled high, whose evil crimes reach the sky - without the death penalty the people's hatred will never be settled."

[Then] the people's accusations began. Fourteen-year-old Yu Jiangji mounted the stage, and with tears flowing pointed to Sun Shengye: "You grabbed my father, killed my grandmother, and forced my mother out of her home." Zhao Wanjin then got on stage, grinding his teeth, "My family had five people in it. You beat my father to death, put me in jail for three years, oppressed my mother to death, starved my two younger sisters to death ..." He was unable to go on for the tears choking his throat. [With this], weeping copiously, all present accused [the counter-revolutionaries] without rest, with sounds that filled the yard.

The people indignantly requested the people's government to put the people first, and execute Wang Hanwu, Sun Yesheng and the others by firing squad. As the death sentence was being carried out, the yard filled with the endless cries of: "Thanks to the Chinese Communist Party!" "Thanks to Chairman Mao!" "Thanks to the People's Government!" 31

In Mulan county, as elsewhere throughout the country, the CCP staged real theatre in which spectacle, state-sanctioned morality and audience participation coalesced into one remarkable show. What evidence we have suggests that in most cases, the accused were roundly condemned, the unjustly victimized given a chance to speak, the emotions of the crowd were engaged, and the event concluded with mass public support for the regime and its actions, with the incidental effect of all present implicitly bloodying their hands in their collusion with the state's violence.

In 1951, the members of the public brought to public accusation meetings were probably not aware that they were part of a show put on by the state, with an appointed supporting role as chorus and object of ideological instruction. Despite the real enough emotions that kongsu hu unleashed, these were heavily stage managed affairs, not the spontaneous events they seemed to be at the time. Only a small proportion of counter-revolutionaries were actually put before the public in this way, and local cadres saved those with the most heinous crimes most likely to be hated by the people for this purpose. Cases against the accused were processed and decided on far in advance of the mass accusation meeting. The individuals who got up to confront

31. Wu Yunfe, "Yi yici gong shenhui" ("Remembering a public trial"), Riwei tongzhi de Mulan (Mulan under Japanese Puppet Rule), Mulan wenshi ziliao, No. 4 (1989), pp. 49-50. 
the accused and "speak bitterness" were specially chosen for the degree to which they would be likely to engage the emotions of the crowd and tended to represent the very old, the very young and women, and they were all coached beforehand as to what to say and when. ${ }^{32}$

The new state-defined morality, sanctions against regime-determined transgressors and participatory "show" all coalesced in the dénouement of the mass campaign. The combination of harshness in dealing with class enemies, and the very public manner in which kongsu hu were played out made for maximal education into regime norms at minimal cost. After the mobilizational phase of the Campaign to Suppress Counter-revolutionaries was over in the late summer of 1951, the CCP almost immediately extended the basic principle by preparing for the next round of mass campaigns to isolate, destroy and reincorporate those other potential social and economic competitors whose services were still to some degree needed by the state: leftover bureaucrats, private entrepreneurs and intellectuals. All were subjected to a similar mix of warning propaganda, sudden arrest, enforced self criticism and on occasion mass accusation meetings between the autumn of 1951 and 1953 - this time with no killing, but also with virtually no resistance being offered.

\section{Limits of Campaigns: Sufan (肃反) in 1955 and Beyond}

Once these preliminaries of regime consolidation were met, the revolutionary People's Republic moved from asserting control over different sectors of society by campaign to envelopment of society with the establishment of the key interlocking institutions of socialism: a hukou that fixed the population, and a centrally managed grain supply system that discriminated heavily in favour of the city over the countryside as the institutional underpinnings of the First Five-Year Plan. The subsequent rapid nationalization of remaining industry and enterprises in urban areas (1955) and collectivization in the countryside (1955-56) were then implemented through bureaucratic campaigns of intense policy push rather than through broadly based campaign mobilization of society.

Yet the CCP was unable simply to give up on its attachment to the notion of mass mobilization and participation, now under the quite different dynamics of work and politics within a work unit. A sufan ("Cleaning Out of Counter-revolutionaries") campaign was launched in 1955, with later surges in 1957-58 (when it overlapped with the Anti-Rightist Campaign) and 1960 (when it overlapped with the "Little Leap"). The initial campaign was geared at checking

32. SMA C21/1/98, "Shanghai gongren canjia zhenya fangeming yundong zongjie baogao" ("Summary report on Shanghai worker's participation in the campaign to suppress counterrevolutionaries"), July or August 1951. 
the unverified credentials of large numbers of people who overnight found themselves working for the state. In theory, the campaign was to have been carried out in the time-honoured manner of stirring up the masses (fadong qunzhong 发动群众): the preparation of materials and struggle sessions, this time carried out within the confines of the small group, with the suggested number of counter-revolutionaries to be rooted out at around 5 per cent per work unit. In practice, things worked quite differently. The guidelines for determining who was a counter-revolutionary (as opposed to the much more common categories of someone with "historical questions" or a "backward political attitude") were so ambiguous that in many work units a minority of activists (jiji fenzi 积极分子), eager to prove themselves and win possible promotion to the Communist Youth League, simply ran away with the process and succeeded in designating upwards of 20 per cent of the work unit as counter-revolutionary. ${ }^{33}$ Worse, despite the best efforts of unit leadership to engage and mobilize the commitments of the masses by the leadership in small group study and accusation sessions, the rank and file resolutely refused to be "stirred up." In 1951, when campaigns and accusation were played out with real drama in public space, most in the participating audience did not understand that their role was that of a chorus in a show put on by the state - albeit one with real consequences for those unfortunate enough to be singled out as enemies. In the summer of 1955, however, with the process of accusation and struggle in the narrower confines of the work place with its more visible hierarchies of power and status, most grasped that campaigns were displays of power put on by the state. They understood that the class-based categories of the redeemable and the enemy were flexible and porous depending on the moment, that individuals could be crushed at any time, and that despite the CCP's adherence to its formula of "stirring up the masses" and criticism and struggle sessions against enemies, it was in not in their interest (except for activists) to draw attention to themselves. It was small wonder that the majority chimed in with only formulaic and timid criticism of designated "targets." As early as 1955, participation in campaigns became rote for the majority, and tied to the prospect of specific reward in an emerging status hierarchy for a designated minority.

Worse, as designated enemies moved from the clearly definable "other" in society to a much less definable "inner" of the work unit, so too did the standards of demarcation become broader and vaguer. In the earliest months of sufan in 1955, beyond the issuing of a vague target of "around 5 per cent" per work unit, there was no way to

33. SMA B123/2/1036, "Di'yi shangye ju zhuanmen xiaozu guanyu liangge duoyue laide suqing ancang fangeming douzheng de chubu zongjie" "Preliminary report of the first commerce bureau's special small group on the struggle against hidden counter-revolutionaries over the last two plus months"), 30 September 1955. After repeated rounds of "adjustments," the final numbers of counter-revolutionaries "cleaned out" was infinitesimally small, at only one or two per work unit. 
distinguish between those with "historical questions" from those with more serious "political questions," or either from counter-revolutionaries, and all criteria were subject to drastic revision in either a more stringent or more accommodating direction depending on signals from above that could and did change at any time. In retrospect, the trajectory over the course of the 1950s was towards greater vagueness and increasing breadth of targeting. In 1951, one really had to have either done something or very recently been a visible part of an organization that was openly and plausibly designated counter-revolutionary. In 1955, one only had to have not come fully clean about prior involvement in an organization deemed counter-revolutionary or suspect; simply refraining from action was enough. By 1957, one only needed to have ever said something that could be construed as counter-revolutionary to be so targeted, and by the end of the 1950s a simple accusation of having thought the wrong kinds of thoughts sufficed.

\section{Conclusion: The Paradoxical Lessons of Success and the Outcome of Failure}

This article considers the period that was by any account the most successful in the history of the revolutionary People's Republic of China: the years of regime consolidation and the establishment of socialism (1949-56). It suggests that the revolutionary state's primary agenda (the integration of the unitary state) and the key vehicle by which it achieved that integration (the campaign) had precedents in the Republican period and contemporary referents in Stalin's Soviet Union, but the particular ways in which campaigns were launched and worked through were very much the product of the Chinese Communist Party's particular ethos of morality paired with popular participation. It argues that campaigns - in their four different forms - were at the heart of the mechanics of regime consolidation and the establishment of socialism, and insofar as these great challenges were met successfully between 1949 and 1956, campaigns were an important part of that aggregate success, however crude, brutal and coercive they might have been towards individuals.

This leaves an important question. If the years between 1949 and 1956 are thought to be in aggregate "successful" (at least in comparison with later periods in the history of the revolutionary PRC), was this a success that was later squandered, and if so, why? Was the ultimately tragic trajectory of the revolutionary PRC something built into the very institutions and ideology of its consolidation in the early to mid-1950s; or, as the official Party historiography would have it, was there a sharp wrong turn made some time after the Eighth Party Congress of autumn 1956? This question is perhaps unanswerable, but the focus on campaigns and their limits suggests some provisional responses. Campaigns in combination with CCP direction from above were such an effective 
mechanism of regime consolidation and the establishment of socialism that this strategy became a victim of its own success when social, political and economic conditions changed. Campaigns did concentrate the implementing power of the bureaucracy, push through a wide range of policies, and even, particularly in the early years of regime consolidation, mobilize significant sectors of the population in support of regime-determined political goals to isolate and destroy those deemed to be "other." Those unfortunate enough to be the targets of campaigns (counter-revolutionaries, landlords, "corrupt" businessmen, "corrupt" cadres, intellectuals of suspect background) suffered severely, but the regime's goals of educating the public in new revolutionary norms, engaging mass support, and destroying both real and potential sources of political, social or economic competition were by and large met. The post-1949 years of consolidation and the establishment of socialism were years in which the CCP's own understanding of what won the civil war continued to serve them well. The mechanics of (re)establishing a vertically integrated state with a revolutionary leadership played out in a policy environment in which, like the civil war itself, enemies were visible and the CCP's own skill at mobilizing the majority against what it defined as the minority resulted in an almost unbelievably rapid set of clearly definable, measurable successes. And even in contemporary China, campaign methods still have significant traction in policy areas where enemies have been clearly definable as a minority "other" (such as the falun gong 法轮功) or as an external enemy to be wiped out (SARS, bird flu).

But when appropriate targets are not both clearly identifiable and compelling, campaigns run into trouble, and these are exactly the kinds of conditions with which the CCP had to deal after the mid1950s. With the social and economic power of alternative social groups destroyed through mass campaigns, coercive domination of society secure and exit options closed off, the CCP's key programmes of consolidation and the establishment of the basic political and economic institutions of socialism had been pushed through much more quickly than anyone had imagined possible. The very improbability of such rapid and thorough successes ultimately made more extravagant forms of voluntarism plausible (if we could win the civil war, tame the economy, push through land reform, wipe out all forms of social and political competition, and both collectivize agriculture and nationalize all private enterprise with so little resistance in such a short period of time, why not be able to leap directly into communism?) and the continued use of the tactics of success (the campaign) unquestioned. The use of campaign methods in a very different policy environment against much less obvious targets combined with other, often contingent, elements: external shocks from de-Stalinization elsewhere in the Leninist world, real objective problems with continuing in a Stalinist trajectory of oneman management and the continued imbalances in the planned 
economy, Mao's own bias against the obvious signs of the domestication of the revolutionary impulse and the collective inability of the CCP leadership to contain his more extravagant impulses, and the CCP's abandonment of its earlier materialist tradition of careful investigation and diagnosis of economic and social relations. All these components reinforced political norms that gave strong incentives to increasingly leftist impulses on the part of local cadres. Tellingly, campaigns continued and in fact intensified, with very different and highly negative aggregate results. The later "mistakes" of the AntiRightist Campaign, the Great Leap Forward and even the Cultural Revolution were neither a dramatic wrong turn nor bred in the bone. They resulted from a set of norms and practices that were fused to the successes of the civil war and 1949-56. Inseparable from the leadership's own myths and understanding of its own successes, campaigns and the uses to which they were put were unable to adapt to the changed environment of the all-enveloping work unit, the collective and the planned economy. Ultimately and ironically, the presumptive lessons of success resulted in later failure, while on the other side of the Taiwan Straits, the presumptive lessons of failure laid a foundation for future success. 